\title{
GERMINATION CHARACTERS AND SEED RESERVE MOBILIZATION DURING GERMINATION OF DIFFERENT WHEAT GENOTYPES UNDER VARIABLE TEMPERATURE REGIMES
}

\author{
M. A. HASAN 1 , J. U. AHMED ${ }^{2}$, T. HOSSAIN ${ }^{2}$, M. M. HOSSAIN ${ }^{3}$ and M. A. ULLAH 4 \\ 1 Department of Crop Botany, Hajee Mohammad Danesh Science and Technology University, \\ Dinajpur, Bangladesh. \\ 2 Department of Crop Botany, Bangabandhu Sheikh Mujibur Rahman Agricultural \\ University, Gazipur, Bangladesh. \\ 3 Department of Horticulture, Bangabandhu Sheikh Mujibur Rahman Agricultural \\ University, Gazipur, Bangladesh. \\ 4 Bangladesh Agricultural Research Institute, Joydebpur, Bangladesh.
}

(Received: 07 April 2003 ; accepted: 11 September 2003)

\begin{abstract}
A laboratory experiment was conducted in the Crop Botany Laboratory at Bangabandhu Sheikh Mujibur Rahman Agricultural University, Salna, Gazipur during 15 October to 15 November, 2001 to study the influence of three temperature regimes $\left(15^{\circ} \mathrm{C}, 25^{\circ} \mathrm{C}\right.$ and $\left.35^{\circ} \mathrm{C}\right)$ on germination characters and seed reserve mobilization in six wheat genotypes. Three heat tolerant (Aghrani, Kanchan and CB-30) and three heat sensitive (Sonora, CB-24 and CB-34) wheat genotypes were used as study material. Speed of germination expressed as rate of germination, coefficient of germination and germination vigor index was found to be increased with increasing temperature from $15^{\circ} \mathrm{C}$ to $35^{\circ} \mathrm{C}$ in all wheat genotypes, but heat tolerant ability based on speed of germination was not found. Generally shoot and root growth of HS genotype in relation to length and dry weight were affected more than those of HT genotypes at high temperature. The amount of seed reserve loss as respiration increased from $25^{\circ} \mathrm{C}$ to $35^{\circ} \mathrm{C}$ in all genotypes, but the increment was higher in Sonora (14.1\%) and CB-24 (13.21\%), moderate in Kanchan (6.36\%), CB-30 (5.22\%) and CB-34 (4.95\%) and lowest in Aghrani (2.03\%). At $15^{\circ} \mathrm{C}$, the amount of seed reserve loss as respiration was also increased from that at $25^{\circ} \mathrm{C}$ in all genotypes except in Aghrani and CB-30. But again the increment was higher in Sonora, CB24 and CB-34 (2.79 to 8.84\%) than that of Kanchan (1.67). In case of Aghrani and CB-30, it even decreased. At $25^{\circ} \mathrm{C}$ temperature the seed reserve mobilization efficiency was significantly higher than that at $15^{\circ} \mathrm{C}$ and $35^{\circ} \mathrm{C}$ in all wheat genotypes. But the heat sensitive genotypes had higher efficiency $(2.58$ to $3.48 \mathrm{~g} / \mathrm{g})$ than that of the heat tolerant genotypes $\left(1.99\right.$ to $2.09 \mathrm{~g} / \mathrm{g}$ ) at $25^{\circ} \mathrm{C}$. Based on reduction of efficiency both at $15^{\circ} \mathrm{C}$ and $35^{\circ} \mathrm{C}$ from that of $25^{\circ} \mathrm{C}$, Sonora, CB-24 and CB-34 (HS) were found more affected than Aghrani, Kanchan and CB-30 (HT).
\end{abstract}

Key words: Germination, seed reserve mobilization efficiency, wheat.

\section{INTRODUCTION}

Late planting of wheat is one of the major reasons of yield reduction because of rice-wheat cropping system. ${ }^{1}$ In Bangladesh, late planting wheat exposed to high temperature at reproductive stage causes reduced kernel number per spike $\mathrm{e}^{1-4}$ and reduced kernel size. ${ }^{5,6}$ The net effect of these is the reduced grain yield. About $60 \%$

Corresponding author 
of the wheat crop is cultivated at late sowing condition after harvesting the transplanted aman rice ${ }^{7}$ and this problem will be further increased due to global warming because in Bangladesh, the annual mean temperature of $25.75^{\circ} \mathrm{C}$ will rise by about $0.21^{\circ} \mathrm{C}$ and $0.39^{\circ} \mathrm{C}$ by 2050 and 2100 , respectively. ${ }^{8}$

In spite of low yield of wheat due to post anthesis heat stress, cultivation of wheat can not be avoided totally, because the irrigation dependent Boro rice cultivation may need to be replaced in future by partially irrigated or non-irrigated wheat cultivation to overcome arsenic problem. Therefore, effort ought to be made to minimize the late sown yield reduction of wheat by screening or developing high temperature tolerant genotypes/ varieties.

Membrane thermostability (MT) test, a widely used and acceptable method to evaluate heat tolerance and heat susceptibility index is used to evaluate yield parameters. Germination characters and seed reserve mobilization may vary in different temperature regimes ${ }^{9}$ because temperature is a modifying factor in germination since it can influence the rate of water and other substrates supply necessary for growth. ${ }^{10}$ The magnitude of variation in seed reserve mobilization may also vary in different genotypes. ${ }^{11}$ But in wheat, the heat tolerance in relation to germination characters and seed reserve mobilization had not been evaluated not only in Bangladesh but also probably in other countries. In the present study, to elucidate heat tolerance of wheat we have investigated germination characters and seed reserve mobilization of wheat during germination in different temperature regimes.

\section{METHODS AND MATERIALS}

The experiment was conducted at the Crop Botany Laboratory, Bangabandhu Sheikh Mujibur Rahman Agricultural University, Salna, Gazipur during 15 October to 15 November, 2001. Three heat tolerant genotypes (Aghrani, Kanchan and CB30 ,) having longer heat killing time and three heat sensitive wheat genotypes (Sonora, CB-24 and CB-34)) having shorter heat killing time in membrane thermostability test. were germinated in three different $\left(15,25\right.$ and $\left.35^{\circ} \mathrm{C}\right)$ temperature regimes. Before placement of seed for germination, the seeds of a genotype were thoroughly mixed and moisture percentage was determined gravimetrically using a portion of the seeds and the remaining seeds were used for the experiment. Individual weight of 30 seeds for each genotype were measured and placed sequentially according to the marking on filter paper soaked with water in sterilized petridishes. Then the petridishes were kept in seed germinator (ATTEMPTER, Advantec, Japan) at 15, 25 and $35^{\circ} \mathrm{C}$. For each temperature, three batches of petridishes each containing 30 seeds were used. Water was added to the petridishes as necessary. 
Rate of germination, co-efficient of germination and germination vigor: Germination was counted at 24 -hour intervals and continued upto the $5^{\text {th }}$ day $(120 \mathrm{~h})$. A seed was considered germinated if plumule and radicle came out and were $>2 \mathrm{~mm}$ long.

The rate of germination was calculated following Krishnasamy and Seshu' ${ }^{12}$ :

Rate of germination $(\%)=\frac{\text { No. of seeds germinated at } 48 \mathrm{~h}}{\text { No. of seeds germinated at } 120 \mathrm{~h}} \times 100$

Co-efficient of germination and vigor index were calculated using the following formulae (Copeland 1976). ${ }^{6}$

Co-efficient of germination $=$

$$
100\left(A_{1}+A_{2}+\longrightarrow+A_{n}\right)
$$$$
A_{1} T_{1}+A_{2} T_{2} \longrightarrow A_{n} T_{n}
$$

Vigor index $=\frac{A_{1}}{T_{1}}+\frac{A_{2}}{T_{2}}+\frac{A_{n}}{T_{n}}$

Where,

$$
\begin{aligned}
& \mathrm{A}=\text { Number of seeds germinated } \\
& \mathrm{T}=\text { Time (days) corresponding to } \mathrm{A} \\
& \mathrm{n}=\text { No of days to final count }
\end{aligned}
$$

Shoot and root length, dry matter partitioning: At $5^{\text {th }}$ day after placement for germination, five seedlings from each petridish were sampled and the shoot and root length of individual seedlings were recorded manually. Then the shoot, root and remaining seeds were dried separately at $70^{\circ} \mathrm{C}$ for $72 \mathrm{~h}$ and weights were recorded. The mean length $(\mathrm{cm})$ and dry weight were calculated for each treatment combination.

Seed reserve mobilization efficiency: Seed reserve mobilization efficiency in the present study is defined as the amount of shoot and root dry matter (g) produced from 1 unit ( $\mathrm{g}$ ) of seed dry weight that was lost as respiration. Thus higher the value of seed reserve mobilization efficiency (SRME), the higher is the efficiency of seed as more seed reserves would be used for producing roots and shoots.

Amount of seed material lost as respiration (SMLR) was calculated as

SMLR $=$ SDW $-($ SHW + RTW + RSW $)$ 
Where,

SDW = Seed dry weight before germination

SHW = Shoot dry weight

RTW = Root dry weight

RSW = Remaining seed dry weight

Seed reserve mobilization efficiency (SRME) was calculated as-

SRME $=\frac{\text { SHW }+ \text { RTW }}{\text { SMLR }}$

\section{Statistical analysis}

The findings were analyzed by partitioning the total variance with the help of computer using MSTAT program. The treatment means were compared using Duncan's Multiple Range Test (DMRT) at $5 \%$ level of significance.

\section{RESULTS AND DISCUSSION}

\section{Germination characteristics:}

Rate of germination was significantly influenced by the interaction effect of temperature regimes and wheat genotypes (Table 1). Co-efficient of germination and germination vigor index of the genotypes were influenced significantly by temperature regimes without expressing any interaction (Table 1). At $15^{\circ} \mathrm{C}$, the rate of germination was nil in all wheat genotypes i.e., none of the seeds were found to be germinated until 48 hours after placement for germination. At $25^{\circ} \mathrm{C}$, all the wheat genotypes showed medium rate of germination (47.85 to $60.80 \%$ ). The highest germination rate was found in CB-30 (98.89\%) genotype at $35^{\circ} \mathrm{C}$, which was statistically similar to all other genotypes except lower germination rate in Aghrani (75.14\%).

Co-efficient of germination was increased with increasing temperature. The lowest value $(24.53 \%)$ was found at $15^{\circ} \mathrm{C}$ in $\mathrm{CB}-24$ genotype at $5^{\text {th }}$ day, which was similar.to all other wheat genotypes at $15^{\circ} \mathrm{C}$. The highest value $(28.54 \%)$ was found in Sonora, which was also statistically similar to all other genotypes at $35^{\circ} \mathrm{C}$. At $25^{\circ} \mathrm{C}$, all the genotypes showed a medium value (26.61 to $27.20 \%$ ).

Germination vigor indices showed an increasing trend with increasing temperature. The lower indices ( 14.80 to 30.90 ) were found at $15^{\circ} \mathrm{C}$, which increased to moderate level ( 28.83 to 30.90 ) at $25^{\circ} \mathrm{C}$ and then to the highest level (33.33 to 37.48 ) at $35^{\circ} \mathrm{C}$ in all wheat genotypes. However, the germination vigor indices increased to a greater extent as the temperature rises from $15^{\circ} \mathrm{C}$ to $25^{\circ} \mathrm{C}$, while with further increase in temperature up to $35^{\circ} \mathrm{C}$ the increase was less. 
Faster speed of germination at higher temperature might be due to rapid hydrolysis and mobilization of seed reserves through higher alpha amylase activity at higher temperature.

Table 1: Rate of germination, co-efficient of germination and germination vigor index in wheat genotypes as influenced by temperature regimes

\begin{tabular}{|c|c|c|c|c|}
\hline Genotypes & $\begin{array}{l}\text { Temp. } \\
\left({ }^{\circ} \mathrm{C}\right)\end{array}$ & $\begin{array}{c}\text { Rate of } \\
\text { of germination }(\%)\end{array}$ & $\begin{array}{c}\text { Co-efficient } \\
\text { of germination }(\%)\end{array}$ & $\begin{array}{l}\text { Germination } \\
\text { vigor index }\end{array}$ \\
\hline \multirow[t]{3}{*}{ Aghrani } & 15 & - & $24.61 \mathrm{c}$ & $20.77 \mathrm{c}$ \\
\hline & 25 & $47.85 \mathrm{e}$ & $27.20 \mathrm{~b}$ & $29.63 \mathrm{~b}$ \\
\hline & 35 & $75.14 \mathrm{c}$ & $28.15 a$ & $33.87 \mathrm{a}$ \\
\hline \multirow[t]{3}{*}{ Kanchan. } & 15 & - & $24.52 \mathrm{c}$ & $14.80 \mathrm{c}$ \\
\hline & 25 & $53.87 \mathrm{de}$ & $26.81 \mathrm{~b}$ & $28.83 \mathrm{~b}$ \\
\hline & 35 & $90.96 \mathrm{ab}$ & $28.28 \mathrm{a}$ & $34.76 \mathrm{a}$ \\
\hline \multirow[t]{3}{*}{ CB-30 } & 15 & - & $24.82 \mathrm{c}$ & $22.41 \mathrm{c}$ \\
\hline & 25 & $53.71 \mathrm{de}$ & $26.61 \mathrm{~b}$ & $29.43 \mathrm{~b}$ \\
\hline & 35 & $98.89 \mathrm{a}$ & $28.54 \mathrm{a}$ & $37.48 \mathrm{a}$ \\
\hline \multirow[t]{3}{*}{ Sonora } & 15 & - & $24.91 \mathrm{c}$ & $21.84 \mathrm{c}$ \\
\hline & 25 & $60.80 \mathrm{~d}$ & $27.08 \mathrm{~b}$ & $30.90 \mathrm{~b}$ \\
\hline & 35 & $98.85 \mathrm{a}$ & $28.54 \mathrm{a}$ & $36.36 \mathrm{a}$ \\
\hline \multirow[t]{3}{*}{ CB-24 } & 15 & - & $24.53 \mathrm{c}$ & $18.96 \mathrm{c}$ \\
\hline & 25 & $58.97 d$ & $26.99 b$ & $29.75 b$ \\
\hline & 35 & $88.66 \mathrm{~b}$ & $28.30 \mathrm{a}$ & $33.33 \mathrm{a}$ \\
\hline \multirow[t]{3}{*}{ CB-34 } & 15 & - & $24.55 \mathrm{c}$ & $20.33 \mathrm{c}$ \\
\hline & 25 & $54.68 \mathrm{de}$ & $26.90 \mathrm{~b}$ & $30.12 \mathrm{~b}$ \\
\hline & 35 & $93.06 \mathrm{ab}$ & $28.26 \mathrm{a}$ & $35.83 \mathrm{a}$ \\
\hline $\mathrm{CV}(\%)$ & & 10.84 & 1.65 & 7.2 \\
\hline
\end{tabular}

Means followed by the same letter (s) did not differ significantly at $5 \%$ level by DMRT

The close relation between germination of wheat seed and alpha amylase activity at various temperatures was reported by Sultana et al. ${ }^{15}$ In respect to speed of germination all wheat genotypes behaved almost similarly at different temperatures, but genotypic differences in speed of germination due to increase in temperature did not appear clearly. 


\section{Height and dry weight of seedling:}

The length and the dry weight of shoot and root of wheat seedlings were influenced significantly by the interaction effect of temperature and wheat genotypes (Table $2)$. The shoot length was lowest in Kanchan $(1.14 \mathrm{~cm}$ ) which was statistically comparable to all other genotypes at $15^{\circ} \mathrm{C}$. Shoot length increased $(5.69$ to $9.03 \mathrm{~cm})$ at $25^{\circ} \mathrm{C}$ which was considered to be the optimum temperature for wheat seedling growth. At $35^{\circ} \mathrm{C}$, shoot length remained more or less the same $(7.53 \mathrm{~cm})$ in Aghrani as at $25^{\circ} \mathrm{C}$ increased in Kanchan $(6.69 \mathrm{~cm})$ and CB-30 $(8.01 \mathrm{~cm})$ but in HS wheat genotypes (Sonora, CB-24 and CB-34), it decreased (6.23 to $8.78 \mathrm{~cm}$ ) as compared to that at $25^{\circ} \mathrm{C}$.

Table 2: Length and dry weight of shoot and root of wheat seedlings as influenced by temperature regimes

\begin{tabular}{|c|c|c|c|c|c|c|c|}
\hline \multirow[t]{2}{*}{ Genotypes } & \multirow{2}{*}{$\begin{array}{c}\text { Temp. } \\
\left({ }^{\circ} \mathrm{C}\right)\end{array}$} & \multicolumn{3}{|c|}{ Length $(\mathrm{cm})$} & \multicolumn{3}{|c|}{ Dry weight (mig) } \\
\hline & & Shoot & Root & $\begin{array}{c}\text { Shoot: } \\
\text { Root }\end{array}$ & Shoot & Root & $\begin{array}{c}\text { Shoot: } \\
\text { Root }\end{array}$ \\
\hline \multirow[t]{3}{*}{ Aghrani } & 15 & $1.28 \mathrm{f}$ & $3.07 \mathrm{~g}$ & $0.41 \mathrm{~h}$ & $1.19 \mathrm{~g}$ & $2.03 \mathrm{gh}$ & $0.60 \mathrm{e}$ \\
\hline & 25 & $7.80 \mathrm{abc}$ & $7.41 \mathrm{c}$ & $1.05 \mathrm{~d}$ & 5.87ef & $4.13 \mathrm{cde}$ & $1.34 \mathrm{~cd}$ \\
\hline & 35 & $7.53 \mathrm{bcd}$ & 4.57 ef & $1.68 \mathrm{~b}$ & $7.01 \mathrm{cde}$ & $2.91 \mathrm{fgh}$ & $2.42 \mathrm{a}$ \\
\hline \multirow[t]{3}{*}{ Kanchan } & 15 & $1.14 \mathrm{f}$ & $3.10 \mathrm{~g}$ & $0.37 \mathrm{~h}$ & $1.00 \mathrm{~g}$ & $2.08 \mathrm{gh}$ & $0.44 \mathrm{e}$ \\
\hline & 25 & $5.69 \mathrm{e}$ & $9.93 \mathrm{~b}$ & $0.59 \mathrm{~g}$ & $6.53 \mathrm{def}$ & $5.51 \mathrm{~b}$ & $1.19 \mathrm{~d}$ \\
\hline & 35 & $6.69 \mathrm{cde}$ & $5.35 \mathrm{e}$ & $1.35 c$ & $8.01 \mathrm{abc}$ & 3.99 cde & $2.01 \mathrm{~b}$ \\
\hline \multirow[t]{3}{*}{ CB-30 } & 15 & $1.25 \mathrm{f}$ & $3.00 \mathrm{~g}$ & $0.42 \mathrm{~h}$ & $1.05 \mathrm{~g}$ & $2.19 \mathrm{gh}$ & $0.49 \mathrm{e}$ \\
\hline & 25 & $7.22 \mathrm{~cd}$ & $11.15 \mathrm{a}$ & $0.64 \mathrm{~g}$ & $6.20 \mathrm{ef}$ & $4.82 \mathrm{bc}$ & $1.30 \mathrm{~cd}$ \\
\hline & 35 & $8.01 \mathrm{fg}$ & $6.41 \mathrm{~d}$ & $1.26 \mathrm{c}$ & $7.47 \mathrm{bcd}$ & $3.62 \mathrm{def}$ & $2.03 \mathrm{~b}$ \\
\hline \multirow[t]{3}{*}{ Sonora } & 15 & $1.31 \mathrm{f}$ & $3.12 \mathrm{~g}$ & $0.42 \mathrm{~h}$ & $1.09 \mathrm{~g}$ & $1.89 \mathrm{~h}$ & $0.60 \mathrm{e}$ \\
\hline & 25 & $9.03 \mathrm{a}$ & $11.57 \mathrm{a}$ & $0.85 \mathrm{e}$ & $8.35 \mathrm{ab}$ & $6.76 \mathrm{a}$ & $1.24 \mathrm{~d}$ \\
\hline & 35 & $8.78 \mathrm{ab}$ & $5.60 \mathrm{de}$ & $1.57 \mathrm{~b}$ & $8.66 a$ & $4.61 \mathrm{bcd}$ & $1.84 \mathrm{~b}$ \\
\hline \multirow[t]{3}{*}{ CB-24 } & 15 & $1.07 \mathrm{f}$ & $2.80 \mathrm{~g}$ & $0.38 \mathrm{~h}$ & $1.07 \mathrm{~g}$ & $1.85 \mathrm{~h}$ & $0.55 \mathrm{e}$ \\
\hline & 25 & $7.23 \mathrm{~cd}$ & $9.42 \mathrm{~b}$ & 0.77 ef & $5.80 \mathrm{f}$ & 4.28 cde & $1.33 \mathrm{~cd}$ \\
\hline & 35 & $6.23 \mathrm{de}$ & $3.37 \mathrm{~g}$ & $1.84 \mathrm{a}$ & $6.57 \mathrm{def}$ & $3.39 \mathrm{ef}$ & $1.94 \mathrm{~b}$ \\
\hline \multirow[t]{3}{*}{ CB-34 } & 15 & $1.21 \mathrm{f}$ & $3.71 \mathrm{fg}$ & $0.33 \mathrm{~h}$ & $1.07 \mathrm{~g}$ & $1.87 \mathrm{~h}$ & $0.56 \mathrm{e}$ \\
\hline & 25 & $7.72 \mathrm{abc}$ & $11.63 \mathrm{a}$ & $0.66 \mathrm{fg}$ & $6.73 \mathrm{def}$ & $5.57 \mathrm{~b}$ & $1.13 \mathrm{~d}$ \\
\hline & 35 & $7.09 \mathrm{~cd}$ & $5.26 \mathrm{e}$ & $1.35 \mathrm{c}$ & $5.79 \mathrm{f}$ & $3.18 \mathrm{efg}$ & $1.50 \mathrm{c}$ \\
\hline $\mathrm{CV}(\%)$ & & 13.49 & 9.73 & 8.28 & 11.92 & 12.12 & 11.41 \\
\hline
\end{tabular}

Means followed by the same letter (s) did not differ significantly at $5 \%$ level by DMRT 
In the case of root length, the lowest value was attained at $15^{\circ} \mathrm{C}$, increased at $25^{\circ} \mathrm{C}$ and thereafter decreased at $35^{\circ} \mathrm{C}$ in all wheat genotypes. At $35^{\circ} \mathrm{C}$, the reduction in root length from that at $25^{\circ} \mathrm{C}$ was lower $(2.84$ to $4.74 \mathrm{~cm}$ ) in Aghrani, Kanchan and CB-30 (HT) than that of heat sensitive Sonora, CB-24 and CB-30 $(5.93$ to $6.37 \mathrm{~cm})$. The adverse effect of higher temperature $\left(35^{\circ} \mathrm{C}\right)$ on root length was more clear than that on shoot length.

The shoot to root length, ratio increased with increasing temperature regimes in all wheat genotypes. It was low at $15^{\circ} \mathrm{C}(0.33$ to 0.42$)$, moderate at $25^{\circ} \mathrm{C}$ $(0.59$ to 1.05$)$ and high at $35^{\circ} \mathrm{C}(1.26$ to 1.84$)$. The increasing shoot to root ratio length with increasing temperature regimes indicated that the root was more affected than the shoot at high temperatures.

Generally, shoot dry weight increased significantly with increasing temperature in all wheat genotypes, except in CB-34 at $35^{\circ} \mathrm{C}$. The increment of shoot dry weight from $25^{\circ} \mathrm{C}$ to $35^{\circ} \mathrm{C}$ was higher in Aghrani, Kanchan and CB-30 (1.27 to $1.48 \mathrm{mg} / \mathrm{seedling})$ than that of Sonora $(0.31 \mathrm{mg} / \mathrm{seedling})$ and CB-24 (0.77 $\mathrm{mg} / \mathrm{seedling}$ ), whereas in CB-34, it decreased. In the case of root dry weight, the highest value was found at $25^{\circ} \mathrm{C}$ and was reduced significantly both at 15 and $35^{\circ} \mathrm{C}$ in all wheat genotypes.

The shoot to root dry weight ratio increased with increasing temperature in all wheat genotypes. Increment of ratio of shoot to root dry weight with increasing temperature indicated that root dry weight was reduced but shoot dry weight increased at higher temperature. Based on increment of shoot to root dry weight ratio from $25^{\circ} \mathrm{C}$ to $35^{\circ} \mathrm{C}$, HT genotypes showed higher increment in shoot dry weight (0.73 to $1.08 \mathrm{mg}$ ) than HS genotypes $(0.37$ to $0.61 \mathrm{mg}$ ).

\section{Seed dry matter distribution:}

The percent seed dry matter accumulated in shoot and root, the amount of dry matter loss during respiration and the dry matter remained in seed at 5 days after placement for germination at $15^{\circ} \mathrm{C}, 25^{\circ} \mathrm{C}$ and $35^{\circ} \mathrm{C}$ showed clear differences among the genotypes (Table 3 and Figure 1). The amount of seed reserve lost due to respiration increased from $25^{\circ} \mathrm{C}$ to $35^{\circ} \mathrm{C}$ in all wheat genotypes, but the increment was higher in Sonora (14.1\%) and CB-24 (13.19\%), moderate in Kanchan (6.36\%) and CB-34 (4.95\%) and lowest in Aghrani (2.03\%). At $15^{\circ} \mathrm{C}$, the amount of respiratory loss of seed reserve was also increased at $25^{\circ} \mathrm{C}$ in all genotypes, except in Aghrani and CB-30. The increment was higher in Sonora, CB-24 and CB-34 (2.79 to $8.84 \%$ ) than in Kanchan (1.67\%). In the case of Aghani and CB-30, it even decreased.

At low temperature $\left(15^{\circ} \mathrm{C}\right)$, the proportion of dry matter distributed to shoot (2.37 to $3.28 \%$ ) and root (4.7 to $5.81 \%$ ) was lower in all genotypes compared to 
those at both higher temperatures $\left(25^{\circ} \mathrm{C} \& 35^{\circ} \mathrm{C}\right)$. Dry matter accumulation in shoot weight was increased significantly over a larger increase in temperature $\left(15^{\circ} \mathrm{C}\right.$ to $35^{\circ} \mathrm{C}$ ). But dry matter accumulation in root was increased over a smaller range of increasing temperature $\left(15^{\circ} \mathrm{C}\right.$ to $\left.25^{\circ} \mathrm{C}\right)$ and thereafter decreased at $35^{\circ} \mathrm{C}$ in all wheat

Table 3: Seed dry matter distribution (\%) at 5 days after placement for germination in different wheat genotypes as influenced by temperature

\begin{tabular}{lccccc}
\hline Genotypes & Temp. & \multicolumn{4}{c}{ Distribution of seed dry matter (\%) } \\
& $\left({ }^{\circ} \mathrm{C}\right)$ & In shoot & In root & Respired & Remain in seed \\
\hline \multirow{2}{*}{ Aghrani } & 15 & $3.05 \mathrm{f}$ & $5.25 \mathrm{gh}$ & $9.18 \mathrm{jk}$ & $82.52 \mathrm{a}$ \\
& 25 & $13.85 \mathrm{e}$ & $10.34 \mathrm{~cd}$ & $13.84 \mathrm{fgh}$ & $61.95 \mathrm{~cd}$ \\
& 35 & $16.89 \mathrm{bcd}$ & $6.87 \mathrm{fg}$ & $15.87 \mathrm{dfg}$ & $60.70 \mathrm{de}$ \\
Kanchan & 15 & $2.37 \mathrm{f}$ & $4.70 \mathrm{~h}$ & $15.71 \mathrm{defg}$ & $77.36 \mathrm{ab}$ \\
& 25 & $15.06 \mathrm{de}$ & $12.76 \mathrm{~b}$ & $14.04 \mathrm{efgh}$ & $58.15 \mathrm{def}$ \\
& 35 & $18.31 \mathrm{ab}$ & $9.12 \mathrm{de}$ & $20.40 \mathrm{~b}$ & $52.17 \mathrm{~g}$ \\
CB-30 & 15 & $2.74 \mathrm{f}$ & $5.72 \mathrm{gh}$ & $13.31 \mathrm{ghi}$ & $78.18 \mathrm{ab}$ \\
& 25 & $16.04 \mathrm{~cd}$ & $12.50 \mathrm{~b}$ & $14.37 \mathrm{efgh}$ & $57.08 \mathrm{defg}$ \\
& 35 & $17.39 \mathrm{bc}$ & $8.71 \mathrm{de}$ & $19.52 \mathrm{bc}$ & $53.71 \mathrm{fg}$ \\
Sonora & 15 & $2.64 \mathrm{f}$ & $4.30 \mathrm{~h}$ & $18.05 \mathrm{~cd}$ & $75.02 \mathrm{~b}$ \\
& 25 & $19.71 \mathrm{a}$ & $15.52 \mathrm{a}$ & $11.19 \mathrm{ij}$ & $53.92 \mathrm{fg}$ \\
& 35 & $18.80 \mathrm{ab}$ & $10.00 \mathrm{~cd}$ & $25.29 \mathrm{a}$ & $45.92 \mathrm{~h}$ \\
CB-24 & 15 & $3.07 \mathrm{f}$ & $5.27 \mathrm{gh}$ & $16.42 \mathrm{de}$ & $75.25 \mathrm{~b}$ \\
& 25 & $15.11 \mathrm{de}$ & $11.14 \mathrm{bc}$ & $7.58 \mathrm{k}$ & $66.17 \mathrm{c}$ \\
& 35 & $15.03 \mathrm{de}$ & $7.74 \mathrm{ef}$ & $20.77 \mathrm{~b}$ & $56.46 \mathrm{efg}$ \\
CB-34 & 15 & $3.28 \mathrm{f}$ & $5.81 \mathrm{gh}$ & $15.69 \mathrm{defg}$ & $75.21 \mathrm{~b}$ \\
& 25 & $17.74 \mathrm{bc}$ & $15.62 \mathrm{a}$ & $12.90 \mathrm{hi}$ & $53.74 \mathrm{fg}$ \\
& 35 & $18.19 \mathrm{ab}$ & $9.82 \mathrm{~cd}$ & $17.95 \mathrm{~cd}$ & $54.45 \mathrm{fg}$ \\
CV(\%) & & 8.78 & 11.65 & 8.36 & 4.72 \\
\hline
\end{tabular}

Means followed by the same letter (s) do not differ significantly at $5 \%$ level by DMRT

genotypes. The results indicated that the optimum temperature for root growth was lower compared to that for shoot growth. Therefore, when the root failed to continue tc increase dry matter at high temperature $\left(35^{\circ} \mathrm{C}\right)$, the shoot was able to continue to gain dry matter showing a higher temperature optimum than root. 


\section{Seed reserve mobilization efficiency (SRME):}

Temperature had a profound effect on seed reserve mobilization efficiency (SRME) in all wheat genotypes (Figure 1). At $25^{\circ} \mathrm{C}$, which is near to optimum temperature $\left(22^{\circ} \mathrm{C}\right)$ for wheat seed germination, the SRME was significantly higher than that of at $15^{\circ} \mathrm{C}$ (Low temperature stress) and $35^{\circ} \mathrm{C}$ (High temperature stress) in all wheat genotypes. Sonora, CB-24 and CB-34 (HS) showed higher SRME (258 to $3.48 \mathrm{~g} / \mathrm{g}$ ) than $\mathrm{HT}$ genotypes $\left(1.99\right.$ to $2.09 \mathrm{~g} / \mathrm{g}$ ) at $25^{\circ} \mathrm{C}$. Based on the amount of reduction in SRME both at $15^{\circ} \mathrm{C}$ and $35^{\circ} \mathrm{C}$ compared to that at $25^{\circ} \mathrm{C}$, the HS genotypes (Sonora, CB-24 and CB-34) experienced larger reduction (1.04 to 2.69g/ g) than heat tolerant Aghrani, Kanchan and CB-30 (0.60 to 1.70g/g).

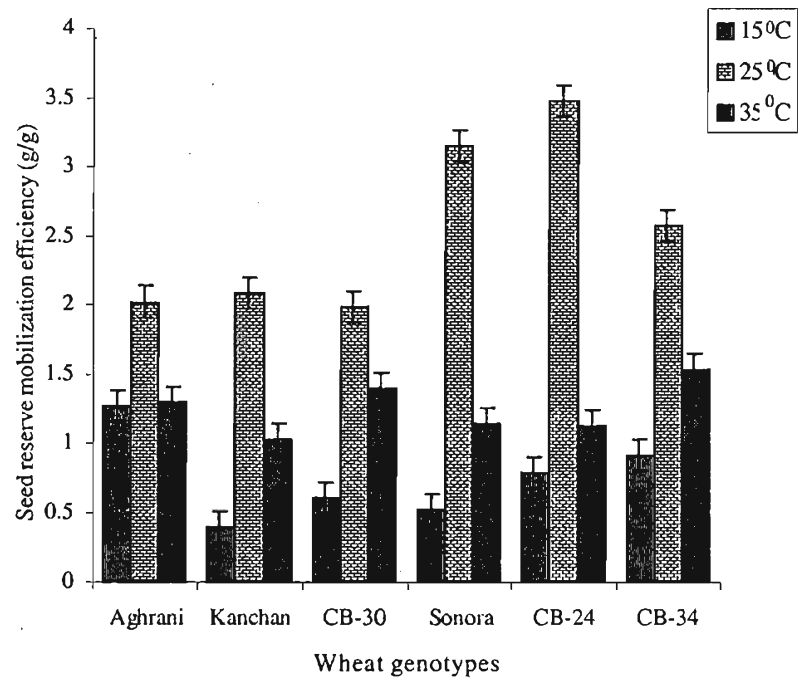

Figure 1: Seed reserve mobilization efficiency in wheat genotype as influenced by temperature

The lowest SRME at $15^{\circ} \mathrm{C}$ temperature suggested that at low temperature, respiration was not linked to a build- up of shoot and root biomass and could have led to thermal dissipation of the respiratory energy by way of alternate oxidase pathway or cyanide resistant pathway..$^{13,14}$ Again at high temperature $\left(35^{\circ} \mathrm{C}\right)$ reduction in SRME under high temperature could be due to increased rate of respiration but the respiratory product somehow failed to accumulate in seedling, mainly in root.

Generally shoot and root growth of HS genotype in terms of length and dry weight were affected more than those of HT genotypes at high temperature. Seed reserve mobilization efficiency of HS genotypes was also affected to a greater extent than that of HT wheat genotypes under high temperature stress. 


\section{References}

1 Islam N., Ahmed S. M., Razzaque M. A., Sufian A. \& Hossain A. (1993). A study on the effect of seeding dates on the yield of wheat varieties. Bangladesh Journal of Agricultural Research 18(1):102-107.

He Z. H. \& Rajaram S. ( 1993). Differential responses of bread wheat characters to high temperature. Euphytica 72: 197-203.

Al-Khatib K. \& Paulsen G. M. (1990). Photosynthesis and productivity during high temperature stress of wheat genotypes from major world regions. Crop Science 30: 1127-1132.

4 Bhatta M. R., Hernandez J. E. \& Lates J. S. (1994). Possibilities of selecting wheats with fast grain filling rate for warmer areas. In: Wheat in Heat-stressed Environments: Irrigated, Dry Areas and Rice-wheat Farming Systems.(Eds. D.A. Saunders \& G..P. Hatel), pp. 375-378. CIMMYT.,Mexico, D.F.

Acevedo E., Nachit M. \& Ferrana G. O. (1991). Effects of heat stress on wheat and possible selection tools for use in breeding for tolerance. In: Wheat for the non-traditional warm areas. (Ed. D. A. Saunders), pp. 401-420.CIMMYT, Mexico D. E.

Asana R. D. \& Saini A. D. (1962). Studies in physiological analysis of yield. V. Grain development in wheat in relation to temperature, soil moisture and changes with age in the sugar content of the stem and in the photosynthetic surface. Indian Journal of Plant Physiology 5: 128-71.

7 Badruddin M., Sauders D. A., Siddique A.B., Hossain M. A., Ahmed M. O. Rahman M. M. \& Parveen S. (1994). Determining yield constraints for wheat production in Bangladesh. In: Wheat in heat stressed environments; irrigated, dry areas and rice-wheat farming systems. (Eds. D. A. Saunders \& G. P. Hettel), pp. 265-271. CIMMYT, Mexico, D. F.

Karmakar S. \& Shrestha M. L. (2000). Recent climatic changes in Bangladesh. SMRC No. 4. SAARC Meteorological Research Centre, Agargaon, Dhaka, Bangladesh.

Penning de Vires F. W. T., Witlage J. M. \& Kremer D. (1979). Rate of respiration and increase in structural dry matter in young wheat, ryegrass and maize plants in relation to temperature, to water stress and to their sugar content. Annals of Botany 44: 595-609. 
10 Wanjura D. F. \& Buxtor D. R. (1972). Hypocotyle and radicle elongation of cotton as affected by soil environment. Agronomy Journal 64: 431-435.

11 Gangadhar Rao D. \& Sinha S. K. (1993). Efficiency of mobilization of seed reserves in Sorghum hybrids and their parents as influenced by temperature. Seed Research 21(2): 97-100.

12 Krishnasamy V. \& Seshu D.V. (1990). Germination after accelerated aging and associated characters in rice varieties. Seed Science and Technology 18: 353-359.

13 Henry M. P. \& Nyns E. T. (1975). Cyanide insensitive respiration: An alternative mitochondrial pathway. Sub cell. Biochem. 4: 1-65.

14 Day D. A., Arnon G. P. \& Laties G. G. (1980). Nature and control of respiratory pathways in plants. The interaction of cyanide-resistant respiration with cyanide-sensitive pathway. In: The biochemistry of plants. (Eds. E. E. Conn \& P. K. Stumpf), pp 197-241. Academic Press, New York, USA.

15 Sultana N., Ikeda T. \& Mitsui T. (2000). GA 3 and proline promote germination of wheat seeds by stimulating alpha-amylase at unfavorable temperatures. Plant Production Science 3(3): 232-237.

16 Copeland L O. (1976). Principles of seed science and technology. Burgess Pub. Com., Minneapolis, Minnesota. pp.164-165. 